University of Nebraska - Lincoln

DigitalCommons@University of Nebraska - Lincoln

Faculty Papers and Publications in Animal

Science

Animal Science Department

1987

\title{
Effect of Weight at Castration on Steer Performance in the Feedlot
}

\author{
M. A. Worrell \\ Clemson University \\ D. C. Clanton \\ don_clanton@comcast.net \\ Chris R. Calkins \\ University of Nebraska-Lincoln, ccalkins1@unl.edu
}

Follow this and additional works at: https://digitalcommons.unl.edu/animalscifacpub

Part of the Animal Sciences Commons

Worrell, M. A.; Clanton, D. C.; and Calkins, Chris R., "Effect of Weight at Castration on Steer Performance in the Feedlot" (1987). Faculty Papers and Publications in Animal Science. 567.

https://digitalcommons.unl.edu/animalscifacpub/567

This Article is brought to you for free and open access by the Animal Science Department at DigitalCommons@University of Nebraska - Lincoln. It has been accepted for inclusion in Faculty Papers and Publications in Animal Science by an authorized administrator of DigitalCommons@University of Nebraska - Lincoln. 


\title{
EFFECT OF WEIGHT AT CASTRATION ON STEER PERFORMANCE IN THE FEEDLOT ${ }^{1}$
}

\author{
M. A. Worrell ${ }^{2}$, D. C. Clanton and C. R. Calkins ${ }^{3}$ \\ University of Nebraska ${ }^{4}$ \\ North Platte 69101
}

\begin{abstract}
One hundred eighty-eight male calves were randomly assigned to one of five treatments at about 6 wk of age to determine the effect of castration at different weights on feedlot performance and carcass characteristics. Calves were castrated at 70, 230, 320 or $410 \mathrm{~kg}$ or left intact. All calves received a 36-mg zeranol implant $60 \mathrm{~d}$ postweaning and were re-implanted every $56 \mathrm{~d}$ for the duration of the trial (196 d). Animals were slaughtered between 14 and 15 mo of age. Intact males gained faster $(P<.05)$ and were more efficient $(P<.05)$ in converting feed to gain than the castrated males. There were no differences $(P>.10)$ in average daily gain (ADG) or feed efficiency (F/G) for males castrated at 70,230 or $410 \mathrm{~kg}$. However, castration at $320 \mathrm{~kg}$ depressed $(P<.05)$ ADG compared with males castrated at $70 \mathrm{~kg}$. Castration at 70 or $230 \mathrm{~kg}$ resulted in higher $(P<.05)$ marbling scores than castrating at heavier weights or not castrating. Intact males had the lowest marbling scores, although not significantly lower than castrating at 320 or $410 \mathrm{~kg}$. Intact males had lower $(\mathrm{P}<.05)$ yield grade scores than males castrated at 70 or $230 \mathrm{~kg}$ but their yield scores were not different $(P>.10)$ from those castrated at 320 or $410 \mathrm{~kg}$. Tenderness of steaks from animals castrated at $70 \mathrm{~kg}$ was greater $(P<.10)$ than for intact males or $410 \mathrm{~kg}$ castrates. Tenderness scores for animals castrated at 230,320 or $410 \mathrm{~kg}$ were not different $(P>.10)$ from the intact males.
\end{abstract}

(Key Words: Castration, Bulls, Steers, Feedlots, Performance, Carcasses.)

\begin{abstract}
Introduction
Considerable interest has developed in growing and finishing young intact males to take advantage of their superior rate and efficiency of gain as compared with the castrated male (Arthaud et al., 1969, 1977; Jacobs et al., 1977a,b; Seideman et al., 1982; Gregory and Ford, 1983). In addition, carcasses from intact males are leaner and have a higher percentage of edible product (Arthaud et al., 1969, 1977; Field, 1971; Ntunde et al., 1977; Gregory and Ford, 1983). However, carcasses from intact males have repeatedly been inferior in quality grade and palatability traits to those from castrated males (Nichols et al., 1964; Bailey et al., 1966; Arthaud et al., 1969, 1977; Jacobs et
\end{abstract}

\footnotetext{
${ }^{2}$ Journal paper no. 8030, Univ. of Nebraska Agr. Res. Division.

${ }^{2}$ Present address: Edisto Res. and Educ. Center, Clemson Univ., Blackville, SC 29817.

${ }^{3}$ Dept. of Anim. Sci., Univ, of Nebraska, Lincoln 68583.

${ }^{4}$ West Central Res. and Ext. Center.

Received April 7, 1986.

Accepted September 22, 1986.
}

al., 1977a,b; Landon et al., 1978; Gregory et al., 1983).

Gregory and Ford (1983) suggested that the majority of the advantage in rate and efficiency of gain of intact males may be expressed by 1 $y r$ of age. Therefore, delaying castration may be an approach for increasing performance in the feedlot without reducing the carcass characteristics of slaughter animals (Ford and Gregory, 1983; Gregory et al., 1983). Comparisons of feedlot performance and carcass characteristics between early and late castrates and with intact males have not been reported in the literature, thus, this study was initiated to make those comparisons.

\section{Experimental Procedures}

One hundred eighty-eight male calves $(3 / 8$ Angus, 3/8 Hereford, 1/8 Gelbvieh, 1/8 Simmental) were randomly assigned to one of five treatments at about $6 \mathrm{wk}$ of age. There were two pens for each treatment blocked over two age groups. One group of calves was born in March and weaned the middle of September; the other group was born in April and weaned the middle of October. There were 9 to 10 
calves in each pen within treatment within age group. The first age group was started on experiment 1 mo before the second; likewise, the experiment was terminated for the first age group 1 mo earlier than the second. Calves were surgically castrated at $70,230,320$ or $410 \mathrm{~kg}$. or left as intact males.

Sixty days postweaning ( $220 \mathrm{~kg}$ weight) the calves were placed on a growing-finishing program for $196 \mathrm{~d}$. During the growing phase $(84 \mathrm{~d})$ the calves received a silage-based ration followed by a step-up program to a highconcentrate ration for the remaining $112 \mathrm{~d}$ of the trial (table 1).

Calves in all five treatments were implanted with $36 \mathrm{mg}$ zeranol at the beginning of the growing phase and were re-implanted every 56 $d$ for a total of four implants per animal. Surgical castration was imposed when average weight of the calves in each treatment group reached pre-planned weights. Stress of castration lasted about $1 \mathrm{wk}$; there were no death losses. All animals were slaughtered between 14 and 15 mo of age.

Hot carcass weights were recorded at slaughter. Outside fat cover, internal fat, ribeye area, quality and yield grades were recorded in the packing house cooler after a 48-h chill. Wholesale ribs from 10 animals in each treatment from the second age group were removed and shipped to the University of Nebraska, Loeffel Meat Laboratory for evaluation. Ether extractable lipids, crude protein and moisture were determined on the ribeye (Longissimus dorsi) muscle trimmed of exterior fat and connective tissue. Steaks were thawed $24 \mathrm{~h}$ at 2 $\mathrm{C}$ and oven-roasted to $35 \mathrm{C}$ in a rotary hearth oven set at $177 \mathrm{C}$, turned and removed when internal temperature reached $70 \mathrm{C}$. They were evaluated by an eight-member trained (Cross et al., 1978) taste panel for muscle fiber tenderness, juiciness, connective tissue amount and overall tenderness. An eight-point rating system ( 1 = extremely tough muscle fibers, extremely dry, abundant connective tissue, extremely tough overall; $8=$ extremely tender muscle fibers, extremely juicy, no connective tissue, extremely tender overall, respectively) was used. Warner-Bratzler shear force was determined on $1.3-\mathrm{cm}$ cores from the steaks.

Data were analyzed using the Statistical Analysis System (SAS, 1982). Analysis of variance for the feedlot performance and carcass characteristics was conducted using a model that contained effects for age, castration treatment, age $x$ castration treatment and pens within age $x$ castration treatment as the sources of variation. Analysis of variance for the rib section chemical analyses and taste panel evaluation was conducted using a model that contained effects for castration treatment and pen within castration treatment as the sources of variation. Differences among the leastsquares treatment means were tested using Bonferroni t-tests.

\section{Results and Discusaion}

Performance. Average daily gain (ADG) during the growing phase was not different (P>.05) among the castration treatments of 70 , 320 or $410 \mathrm{~kg}$ and the intact males (table 2). Animals castrated at $230 \mathrm{~kg}$ (the beginning of the growing phase) gained less than those castrated at $410 \mathrm{~kg}$ and the intact males $(P<.05)$ and males castrated at $70 \mathrm{~kg}(\mathrm{P}<.10)$. Males castrated at $230 \mathrm{~kg}$ tended to be less efficient than those on the other treatments; however, there were no differences $(P>.10)$ in efficiency among treatments during the growing phase.

Castration at $320 \mathrm{~kg}$ (the end of the growing phase) resulted in slower gains $(\mathrm{P}<.05)$ during the finishing phase than castration at 70 or 230 $\mathrm{kg}$ or noncastration. No difference was detected in average daily gain between castration at 320 or $410 \mathrm{~kg}$. Intact males gained faster $(P<.05)$ than all other groups. There were no differences $(P>.10)$ in gains between castration at $410 \mathrm{~kg}$ and castration at $70 \mathrm{~kg}$ or $230 \mathrm{~kg}$. Feed efficiency during the finishing phase followed a

TABLE 1. DIET COMPOSITION AND ANALYSIS

\begin{tabular}{|c|c|c|}
\hline Item & Growing & Finishing \\
\hline \multicolumn{3}{|l|}{ Ingredienta } \\
\hline Corn & 40 & 80 \\
\hline Corn silage & 40 & 12 \\
\hline Alfalfa & 12 & \\
\hline $40 \%$ protein supplement & 8 & \\
\hline $32 \%$ protein supplement & & 8 \\
\hline \multicolumn{3}{|l|}{ Analysis $b$} \\
\hline $\mathrm{NE}_{\mathrm{m}}, \mathrm{Mcal} / \mathrm{kgc}$ & 1.82 & 2.12 \\
\hline $\mathrm{NE}_{\mathrm{g}}, \mathrm{Mcal}_{\mathrm{c}} / \mathrm{kg}_{\mathrm{g}} \mathrm{C}$ & 1.20 & 1.45 \\
\hline Crude protein, $\%$ & 12.30 & 11.50 \\
\hline
\end{tabular}


TABLE 2. EFFECT OF WEIGHT AT CASTRATION ON PERFORMANCE IN FEEDLOT

\begin{tabular}{|c|c|c|c|c|c|c|}
\hline \multirow[b]{2}{*}{ Trait } & \multicolumn{4}{|c|}{ Weight at castration, $\mathrm{kg}$} & \multirow{2}{*}{$\begin{array}{l}\text { Intact } \\
\text { males }\end{array}$} & \multirow[b]{2}{*}{$S^{a}$} \\
\hline & 70 & 230 & 320 & 410 & & \\
\hline $\begin{array}{l}\text { Beginning wt, kg } \\
\text { Final wt, kgb }\end{array}$ & $\begin{array}{l}221 \\
487 \mathrm{~cd}\end{array}$ & $\begin{array}{l}222 \\
484 c\end{array}$ & $\begin{array}{l}227 \\
468^{c}\end{array}$ & $\begin{array}{l}223 \\
482^{c}\end{array}$ & 222 & $\begin{array}{l}28.77 \\
40.10\end{array}$ \\
\hline \multicolumn{7}{|l|}{ Daily gain, kg } \\
\hline Growing (84 d) & $1.24^{\mathrm{cd}}$ & $1.18^{\mathrm{d}}$ & $1.20^{\mathrm{cd}}$ & $1.26^{\mathrm{c}}$ & $1.26^{\mathrm{c}}$ & .16 \\
\hline Finishing $\mathrm{b}(112 \mathrm{~d})$ & $1.34 \mathrm{C}$ & $1.34^{\mathrm{C}}$ & $1.17^{\mathrm{d}}$ & $1.26^{\mathrm{cd}}$ & $1.54^{\mathrm{e}}$ & .18 \\
\hline Combined $b(196 d)$ & $1.30^{\mathrm{c}}$ & $1.28^{\mathrm{cd}}$ & $1.18^{\mathrm{d}}$ & $1.26^{\mathrm{cd}}$ & $1.42^{\mathrm{e}}$ & .13 \\
\hline $\mathrm{SE}$ coefficient $\times 100^{\mathrm{a}}$ & 18.40 & 51.69 & 20.52 & 27.75 & 16.59 & \\
\hline \multicolumn{7}{|l|}{ Feed efficiency } \\
\hline Growing (84 d) & 5.80 & 6.16 & 5.94 & 5.75 & 5.65 & .34 \\
\hline Finishing $b(112 d)$ & 5.92 & 6.00 & 6.56 & 6.36 & 5.74 & .48 \\
\hline Combined $b(196 \mathrm{~d})$ & $6.05^{c}$ & $5.88^{\mathrm{cd}}$ & $6.71^{\mathrm{c}}$ & $6.35^{c}$ & $4.92^{\mathrm{d}}$ & .42 \\
\hline SE coefficient $\times 100^{a}$ & 50.00 & 50.00 & 50.00 & 50.00 & 50.00 & \\
\hline
\end{tabular}

\footnotetext{
${ }^{a}$ Standard error (SE) of a least-squares mean can be determined by multiplying the SE coefficient by the standard deviation (SD) of a trait; e.g., SE of final wt for intact males $=.1659 \times 40.10=6.65$.

${ }^{b}$ Adjusted to $62 \%$ dressing percentage.

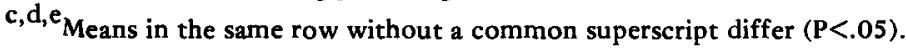

similar pattern to gains, although differences among the treatments were not signficant ( $\mathrm{P}>$.10).

Combining the growing and finishing phases, animals castrated at $320 \mathrm{~kg}$ had lower $(\mathrm{P}<.05)$ gains than either males castrated at $70 \mathrm{~kg}$ or those left intact. No differences $(P>.10)$ in gains were observed among those castrated at 70,230 or $410 \mathrm{~kg}$. Intact males gained faster $(\mathbf{P}<.05)$ for the entire feeding period than any of the castrated groups. Overall feed efficiency followed a similar pattern, i.e., intact males were more efficient $(\mathrm{P}<.05)$ than males castrated at 70,320 or $410 \mathrm{~kg}$ and males castrated at 230 $\mathrm{kg}(\mathrm{P}<.10)$. Animals castrated at 320 or $410 \mathrm{~kg}$ tended to be less efficient than the other castrate groups; however, feed to gain was similar $(\mathrm{P}>.10)$ for all castration treatments.

Carcass Cbaracteristics. Intact males had heavier $(\mathrm{P}<.05)$ carcasses than the males castrated at 230,320 or $410 \mathrm{~kg}$. While intact males appeared to have heavier carcasses than those castrated at $70 \mathrm{~kg}$, the difference was not significant. Those castrated at $320 \mathrm{~kg}$ produced

TABLE 3. EFFECT OF WEIGHT AT CASTRATION ON CARCASS CHARACTERISTICS

\begin{tabular}{|c|c|c|c|c|c|c|}
\hline \multirow[b]{2}{*}{ Trait } & \multicolumn{4}{|c|}{ Weight at castration, $\mathrm{kg}$} & \multirow{2}{*}{$\begin{array}{l}\text { Intact } \\
\text { males }\end{array}$} & \multirow[b]{2}{*}{ SD $^{\mathbf{a}}$} \\
\hline & 70 & 230 & 320 & 410 & & \\
\hline Carcass wt, kg & $302^{\mathrm{cd}}$ & $300^{c}$ & $290^{c}$ & $299 \mathrm{c}$ & $318^{d}$ & 24.88 \\
\hline Marbling score ${ }^{b}$ & $5.0^{\mathrm{c}}$ & $5.4^{\mathrm{C}}$ & $4.2^{\mathrm{d}}$ & $4.0^{d}$ & $3.5 \mathrm{~d}$ & 1.15 \\
\hline Yield grade & $2.7^{c}$ & $3.0^{c}$ & $2.6^{\mathrm{cd}}$ & $2.5 \mathrm{~cd}$ & $2.3^{\mathrm{d}}$ & .52 \\
\hline Ribeye area, $\mathrm{cm}^{2}$ & $77.1^{\mathrm{c}}$ & $69.7^{\mathrm{c}}$ & $74.8^{\mathrm{c}}$ & $79.0^{\mathrm{c}}$ & $84.2^{\mathrm{d}}$ & 7.10 \\
\hline Fat covering, $\mathrm{cm}$ & $1.15^{\mathrm{c}}$ & $1.31^{\mathrm{cd}}$ & $1.10^{\mathrm{cd}}$ & $1.05^{\mathrm{cd}}$ & $.97 \mathrm{~d}$ & .33 \\
\hline Kidney, pelvic, heart fat \% & $2.1^{\mathrm{e}}$ & $1.9 \mathrm{ef}$ & $1.8^{\mathrm{ef}}$ & $1.9 \mathrm{ef}$ & $1.8^{\mathrm{f}}$ & .41 \\
\hline SE coefficient $\times 100^{a}$ & 18.40 & 51.82 & 20.48 & 27.85 & 17.00 & \\
\hline
\end{tabular}

\footnotetext{
${ }^{a}$ Standard error (SE) of a least-squares mean can be determined by multiplying the SE coefficient by the standard deviation (SD) of a trait; e.g., SE of carcass wt for intact males $=.1700 \times 24.88=4.23$.

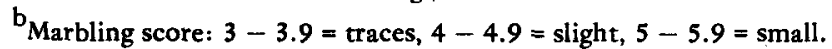

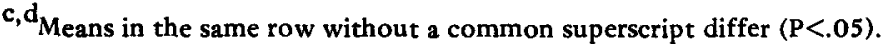

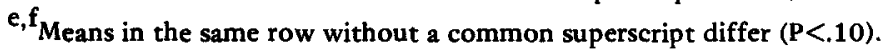


TABLE 4. EFFECT OF WEIGHT AT CASTRATION ON CHEMICAL ANALYSES FROM RIB SECTIONS

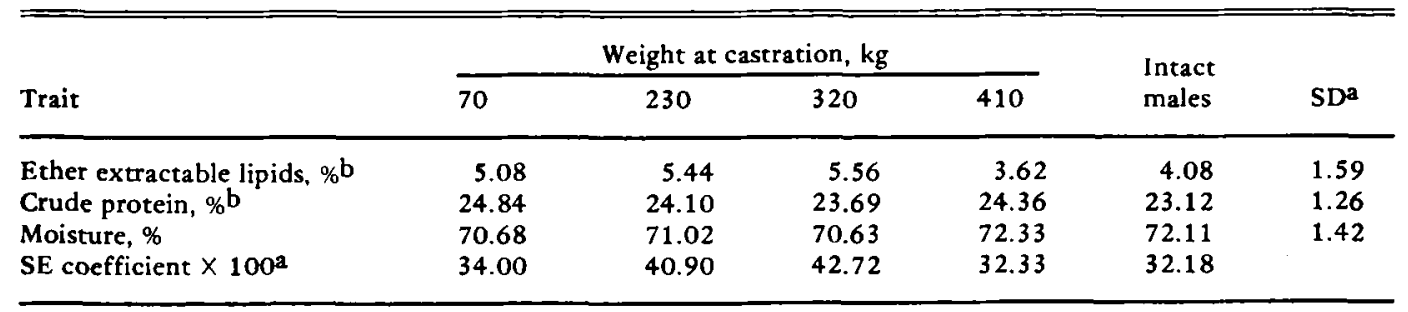

\footnotetext{
${ }^{2}$ Standard error (SE) of a least-squares mean can be determined by multiplying the SE coefficient by the standard deviation (SD) of a trait; e.g., SE of crude protein for intact males $=.3218 \times 1.26=.4055$.

${ }^{b}$ Dry matter basis.
}

lighter carcasses than any of the other treatment groups; however, they were different $(\mathrm{P}<.05)$ only from the intact males (table 3 ).

Castration at weights of $230 \mathrm{~kg}$ or less resulted in higher marbling scores $(P<.05)$ than castrating at heavier weights or not castrating. There were no differences $(P>.05)$ in marbling scores among the castration treatments of 320 and $410 \mathrm{~kg}$ and the intact males. Intact males had lower $(\mathrm{P}<.05)$ yield grade scores than males castrated at 70 or $230 \mathrm{~kg}$, but, were similar ( $P>.05)$ compared with males castrated at 320 or $410 \mathrm{~kg}$.

Intact males and males castrated at $410 \mathrm{~kg}$ tended to have lower $(P>.10)$ ether-extractable lipids in the ribeye than males castrated at 70 , 230 or $320 \mathrm{~kg}$, indicating a lower fat content in the lean (table 4). Moisture content in the ribeye paralleled in reverse the lipids content. The somewhat higher moisture and lower ether-extractable lipids of the $410-\mathrm{kg}$ castrates and intact males appears to agree with carcass marbling score, fat covering, and kidney, pelvic and heart fat measurements (table 3 ). There were no differences in crude protein among the treatments.

No differences $(\mathrm{P}>.10)$ were evident in juiciness of steaks from castrated animals or intact males (table 5). Overall tenderness of steaks from males castrated at $70 \mathrm{~kg}$ was greater $(\mathrm{P}<.10)$ than for males castrated at $410 \mathrm{~kg}$ or the intact males. Tenderness scores for animals castrated at 230 or $320 \mathrm{~kg}$ were intermediate between males castratcd at $70 \mathrm{~kg}$ and males

TABLE 5. EFFECT OF WEIGHT AT CASTRATION ON TASTE PANEL EVALUATION AND SHEAR FORCE ANALYSIS OF STEAKS FROM RIB SECTIONS

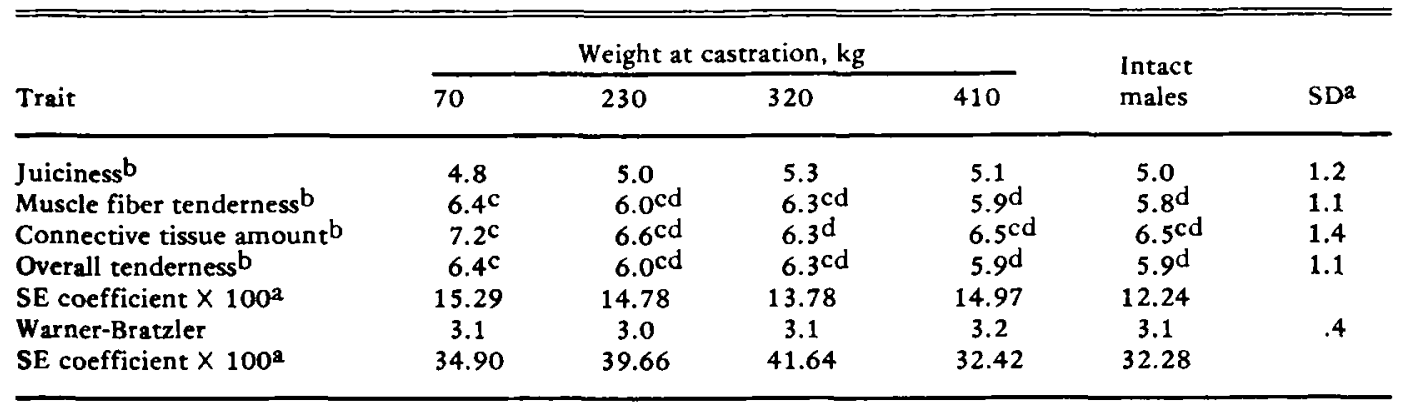

\footnotetext{
${ }^{2}$ Standard error (SE) of a least-squares mean can be determined by multiplying the SE coefficient by the standard deviation (SD) of a trait; e.g., SE of juiciness for intact males $=.1224 \times 1.2=.1469$.

${ }^{b}$ Eight-point rating scale: 1 = extremely tough muscle fibers, extremely dry, abundant connective tissue, extremely tough overall; 8 = extremely tender muscle fibers, extremely juicy, no connective tissue, extremely tender overall, respectively.

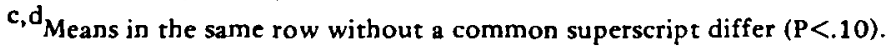


castrated at $410 \mathrm{~kg}$ or intact males. However, treatment groups were not different $(P>.10)$ for Warner-Bratzler shear values.

The data from this study indicate that castration of male calves should be performed at or before $230 \mathrm{~kg}$ to achieve higher carcass qualities, or males should be left intact to obtain increased feedlot performance, efficiency and carcass leanness. It may be possible to improve carcass quality of late castrates or intact males by increasing time on feed; however, longer feeding periods for intact males may reduce feed efficiency and gains to levels that are similar to levels of early castrates.

\section{Literature Cited}

Arthaud, V. H., C. H. Adams, D. R. Jacobs and R. M. Koch. 1969. Comparison of carcass traits of bulls and steers. J. Anim. Sci. 28:742.

Arthaud, V. H., R. W. Mandigo, R. M. Koch and A. W. Kotula. 1977. Carcass composition, quality and palatability attributes of bulls and steers fed different energy levels and killed at four ages. J. Anim. Sci. 44:53.

Bailey, C. M., C. L. Probert, P. Richardson, V. R. Bohman and J. Chancerelle. 1966. Quality factors of the longissimus dorsi of young bulls and steers. J. Anim. Sci. 25:504.

Cross, H. R., R. Moen and M. S. Stanfield. 1978. Training and testing of judges for sensory analysis of meat quality. Food Technol. 32(7):48.

Field, R. A. 1971. Effect of castration on meat quality and quantity. J. Anim. Sci. 32:849.

Ford, J. J. and K. E. Gregory. 1983. Effects of late castration and zeranol on feedlot performance and carcass characteristics of bovine males. J. Anim. Sci. 57:286.

Gregory, K. E. and J. J. Ford. 1983. Effects of late castration, zeranol and breed group on growth, feed efficiency and carcass characteristics of late maturing bovine males. J. Anim. Sci. 56:771.

Gregory, K. E., S. C. Seideman and J. J. Ford. 1983. Effects of late castration, zeranol and breed group on composition and palatability characteristics of longissimus muscle of bovine males. J. Anim. Sci. 56:781.

Jacobs, J. A., C. E. Hurst, J. C. Miller, A. D. Howes, T. L. Gregory and T. P. Ringkob. 1977a. Bulls versus steers. I. Carcass composition, wholesale yields and retail values. J. Anim. Sci. 46:695.

Jacobs, J. A., J. C. Miller, E. A. Sauder, A. D. Howes, A. A. Araji, T. L. Gregory and C. E. Hurst. $1977 \mathrm{~b}$. Bulls versus steers. II. Palatability and retail acceptance. J. Anim. Sci. 46:699.

Landon, M. E., H. B. Hedrick and G. B. Thompson. 1978. Live animal performance and carcass characteristics of beef bullocks and steers. J. Anim. Sci. 47:151.

Nichols, J. R., J. H. Ziegler, J. M. White, E. M. Kesler and J. L. Watkins. 1964. Production and carcass characteristics of Holstein-Friesian bulls and steers slaughtered at 800 or 1000 pounds. J. Dairy Sci. 47:179.

Ntunde, B. N., W. R. Usborne and G. C. Ashton. 1977. Responses in meat characteristics of HolsteinFriesian males to castration and diet. Can. J. Anim. Sci. 57:449.

SAS. 1982. SAS User's Guide: Statistics. Statistical Analysis System Inst., Inc., Cary, NC.

Seideman, S. C., H. R. Cross, R. R. Oltjen and B. D. Schonbacher. 1982. Utilization of the intact male for red meat production. A review. J. Anim. Sci. $55: 826$. 